\title{
Effect of Leadership Style, Motivation, and Giving Incentives on the Performance of Employees-PT. Kurnia Wijaya Various Industries
}

\author{
Zaenal Mustafa Elqadri ${ }^{1}$, Priyono ${ }^{2}$, Rahayu Puji Suci $^{3} \&$ Teddy Chandra ${ }^{4}$ \\ ${ }^{1}$ Faculty of Economics, University of Islam Indonesia Yogyakarta, Indonesia \\ ${ }^{2}$ Department of Management Studies Program, Faculty of Economics, University of PGRI Adi Buana Surabaya, \\ Indonesia \\ ${ }^{3}$ Department of Management Studies Program, Faculty of Economics, University of Widya Gama Malang, \\ Indonesia \\ ${ }^{4}$ School of Business, Pelita Indonesia, Pekanbaru, Indonesia \\ Correspondence: Priyono, Department of Management Studies Program, Faculty of Economics, University of \\ PGRI ADI Buana Surabaya, Indonesia. Tel: 62-081-216-974-878. E-mail: priyono.unu_sidoarjo@yahoo.com
}

Received: April 12, 2015 Accepted: May 14, 2015 Online Published: September 28, 2015

doi:10.5539/ies.v8n10p183 URL: http://dx.doi.org/10.5539/ies.v8n10p183

\begin{abstract}
This study aims to identify and examine the importance of leadership style, motivation, and incentives to improve employee performance. Variables examined as factors that affect performance of employees were style of leadership (X1), motivation (X2), and the provision of incentives (X3).

The population of this study was all employees in the Sales Department MT PT. Kurnia Wijaya Various Industries, amounting to 20 people. Data collection techniques were documentation and questionnaires. This study also used multiple linear regressions to analyze the data.

It indicates that the level of the relationship between leadership style (X1), motivation (X2), and the provision of incentives (X3) on employee performance $(\mathrm{Y})$ is very strong. This is because the value of the correlation coefficient is $R=0,985 \mathrm{a}$ is in the interval between 0.80 - coefficient of 1.000 . While the coefficient of determination of $\mathrm{R} 2=0.971$, indicating that the independent variable (leadership style, motivation, and incentives) can influence the dependent variable (performance of employees) at $97.1 \%$ while the remaining $2.9 \%$ is influenced by other factors not examined.
\end{abstract}

Keywords: leadership style, motivation, incentives and employee performance

\section{Introduction}

Every company in achieving the goal, of course, takes the role of human resources (HR), this is in line with the opinions Simamora (1997) (1) which states that human resources are considered important because they can affect the efficiency and effectiveness of the organization. Without HR in the company, performance improvement is hard, while according to Gibson et al. (1996) organization performance depends on the performance of its employees.

Employee performance is one of the mandatory aspect to be considered by a company, because the performance of the employee requires the organization to achieve its goals (Surbakti, 2013). According to Hasibuan (2005), the performance is the result of work achieved in executing the tasks assigned to employees based on the skills, experience, and sincerity as well as time.

For high employee performance (maximum), we need a leader who is able to manage his/her human resources. This is supported by statements Alberto et al., In Wati (2010) that leadership style has a strong positive effect on performance. A leader has a way to influence others or subordinates such a way that the person is willing to do the will of the leadership to achieve company goals.

In the organization, the most important element in addition to the style of leadership is the motivation of subordinates. Based on Malthis' statement in Surbakti (2013), motivation is a desire in a person that causes the person to be concerned to take actions. This implies from the influence of leadership style. However, the other factor that takes effect on the performance of employees is the provision of incentives. Pasaribu (2008) explained 
that the incentive is an important driving tool. Incentive compensation is a form of material provided by the company for its employees who have worked loyally. Therefore, many employees tend to try even harder if the remuneration received by giving satisfaction to what was expected.

Such condition lead to the company's performance to decrease therefore, during the period 2010-2013, it is known there is a slight decrease in the level of work absenteeism, and not many employees who want to move so that the employee is considered to increase performance.

From observation of this, the authors aimed to examine the influence of leadership style, motivation and incentives on employees performance at PT. Kurnia Wijaya Various Industries, in Sidoarjo, Indonesia.

Based on the background of the above problems so that the formulations of research questions are:

1) What leadership style affects the performance of employees at PT. Kurnia Wijaya various Industry?

2) What was the motivation affects employee performance in PT. Kurnia Wijaya various Industry?

3) Do incentives affect employee performance in PT. Kurnia Wijaya various Industries?

4) What style of leadership, motivation, and incentives affect the performance of employees at PT. Kurnia Wijaya various Industry?

\section{Literature Study}

\subsection{Research Accomplished}

In the writing process, the researchers refer to several previous studies include the following: Hardi Pasaribu 2008, Based on the t-test results obtained t financial incentive variable (X1) of 3.383 and non-financial incentives $t$ arithmetic variable (X2) of 4.331. While based test-f obtained $F$ arithmetic financial incentive variable (X1) and non-financial incentives (X2) is 38.945 with level sig. $0,000 \mathrm{~b}$ so $0,000 \mathrm{~b}<0.05$ then $\mathrm{H} 0$ is rejected and $\mathrm{Ha}$ accepted which means simultaneously variable financial incentives and non-financial incentives showed highly significant effect on work motivation Revenue Service employee North Sumatra Province.

Ozzy Eka Marta 2011, the analysis used in this study is the technique of multiple linear regression analysis. Leadership style positive effect on employee responsiveness; organizational culture provides a positive effect on responsiveness; and responsiveness has a positive influence on the performance of employees.

Marwan Petra Surbakti, 2013, Based on the analysis concluded that transformational leadership and motivational variables can affect employee performance variables at PT KAI Daop IV Semarang.

Research findings from different countries and different school contexts has revealed the impact of the strong leadership in securing the development of schools and changes (for example, Hopkins, 2001a; West, Jackson, Harris, \& Hopkins, 2000). Hopkins (2001b) highlights the importance of transformational leadership and learning practices in accomplishing school improvement at schools facing challenging circumstances.

The existing literature also shows that the most popular theories is transactional and transformational models identify more than 20 years ago (Burns, 1978; Hoy \& Miskel, 2008) and lately reinvented through terms such as 'liberation' (Tampoe, 1998), 'educating' (Duignan \& McPherson, 1992), the 'invitation' (Stoll \& Fink, 1996) and "moral” leadership (Sergiovanni, 1992).

According to Brenninkmeyer and Spillane (2008, p. 436), a recent study paints a picture of the head of school as someone who spends a lot of time to solve the problem of learning in school, and that its performance in solving problems that have the real effect on the outcome of students at the school. That is clear from the literature, and from the effective school, is that a successful leader will not only determine the direction but they are also the values and practices are consistent with the Model of the school, so the "goal that may initially seem tube split into integral" (Sergiovanni, 1995: 119). Effective leaders are proactive and seek assistance as needed. They also kept the learning program and school culture that is conducive to learning and professional growth. However, an effective learning and administrative Leadership required to carry out the process of change (Hoy \& Miskell, 2008).

\subsection{Theoretical Basis}

\subsubsection{Definition of Leadership Style}

Ivansevich and Matteson (2008) states that leadership is the ability to use the influence of the environment or situation of the organization, to produce a meaningful effect and environment impact on the achievement of challenging objectives.

Leadership is the process of influencing others to act in order to achieve the goals that have been set. Leadership 
always involves someone (leader) to influence a person's behavior follower or followers in a situation.

Robbin (2002) defines leadership as the ability to influence a group's goals. Meanwhile, according to Isaac and Hendry (2003), leadership is a person's ability to control or influence others or different societies toward a particular achievement. Priyono (2011) defines leadership is someone who can influence others to achieve his goal. Path Goal theory (the theory of the destination path) of leadership have been developed to explain how a leader's behavior affects the satisfaction and performance of subordinates. This theory was first proposed by Evans (1970) and House (1971), Formulate this theory with a more rigorous version to include situational variables. The theory was further purified by several authors such as Evans (1974), House and Dessler (1974), House and Mitchell (1974), and House (1996).

According Wati (2010) states that the leadership style is the way leaders to influence others or subordinates such a way that the person is willing to do the will of the leadership to achieve organizational goals although personally it may be unpopular.

During its development, the study of leadership evolved in line with the progress of time, categorized Yukl (2005: 12) into five approaches: (1) characteristics approach, (2) behavioral approaches; (3) approach the power influence; (4) wide approach situational; and (5) Last Thoughts on effective leadership delivered by a group of experts who try to "turn" back theory "trait" or the particular traits of a person so that he can be a leader. Robert House conveys leadership theory by suggesting that effective leadership using dominance, have self confidence, influence and display high morality to increase levels of charismatic (Ivancevich et al., 2008).

\subsubsection{Integrative Approach}

The theory that supports the definition of leadership style according to some experts, namely: During its development, the study of leadership evolved in line with the progress of time, categorized Yukl (2005: 12) into five approaches: (1) characteristics approach, (2) behavioral approaches; (3) approach the power - influence; (4) wide approach situational; and (5) an integrated approach Fiedler leadership model (1967) referred to as the contingency model because the model assumes that the contribution of the leader of the effectiveness of the group's performance depends on the manner or style of leadership (leadership style) and the suitability of the situation (the favourable of the situation) that it faces.

Sedarmayanti (2007) states that the style of leadership is the norm of behavior used a manager at the time of influencing the behavior of subordinates. A person who is obliged to carry out the functions of management affect subordinate employees in order to continue to perform the task well, is dedicated to the organization and still feel obliged to achieve organizational goals.

Effendi (1992) defines that style of leadership is how a leader carry out its activities in an effort to guide, guiding, directing, and controlling the thoughts, feelings, or behavior of someone or some people to achieve certain goals

Final thought regarding effective leadership delivered by a group of experts who try to "turn" back theory "trait" or the particular traits of a person so that he can be a leader. Robert House conveys leadership theory by suggesting that effective leadership using dominance, have self confidence, influence and display high morality to increase levels of charismatic (Ivancevich et al., 2008, p. 213). Path Goal theory (the theory of the destination path) of leadership have been developed to explain how a leader's behavior affects the satisfaction and performance of subordinates. This theory was first proposed by Evans (1970) and House (1971). House (1971) formulates this theory with a more rigorous version to include situational variables. The theory was further purified by several authors such as Evans (1974), House and Dessler (1974), House and Mitchell (1974), and House (1996).

\subsection{Understanding Motivation}

According Hasibuan (2005) motivation is derived from the Latin, meaning Mavere impulse or motive power. Motivation questioned by encouraging employees' passion, to want to work hard to provide all the capabilities and skills to achieve company goals.

The theory that supports the definition of motivation, according to some experts, namely:

According to Robbins (2007) motivation is the willingness to do high-level efforts to achieve organizational goals, conditioned by the effort's ability to satisfy the needs of individuals.

According to Cascio in Hasibuan (2005) motivation is a force resulting from a person's desire to satisfy his needs.

Rival (2010) which states that motivation is a set of attitudes and values that influence individuals to achieve specific things in accordance with the individual goals. Attitudes and values is an invisible something that gives 
strength to encourage individuals to behave in achieving the goal.

\subsection{Understanding Incentives}

Incentives interpreted as a form of payment that is linked to performance and gains haring, as employee profit sharing as a result of improved performance. This system is another form of direct compensation beyond salaries and wages are fixed compensation, the so-called system of compensation based on performance (Rivai, 2010).

\subsection{Understanding Performance}

Performance is something that is achieved or achievement shown (Indonesian Dictionary, 2001). The theory that supports the definition of motivation, according to some experts, namely: Performance (performance) is an overview of the level of achievement of the implementation of the activities/programs/policies in realizing the goals, objectives, mission and vision of the organization as stated in the strategic planning of an organization. The term is often used to refer to the performance or achievements of the success rate of individuals and groups of individuals (Parlinda, 2012). According to Robbins (2007), the performance is the result of an evaluation of the work performed individual compared with the established criteria together, the notion of performance as a result of the quality and quantity of work accomplished individuals in carrying out their duties in accordance with the responsibilities given.

\subsection{Framework Concept}

A conceptual framework for the review of the literature which poured in form scheme reflecting the linkages between the factors cause the onset of the problem and the problem itself. As for the conceptual framework of the study is as follows:

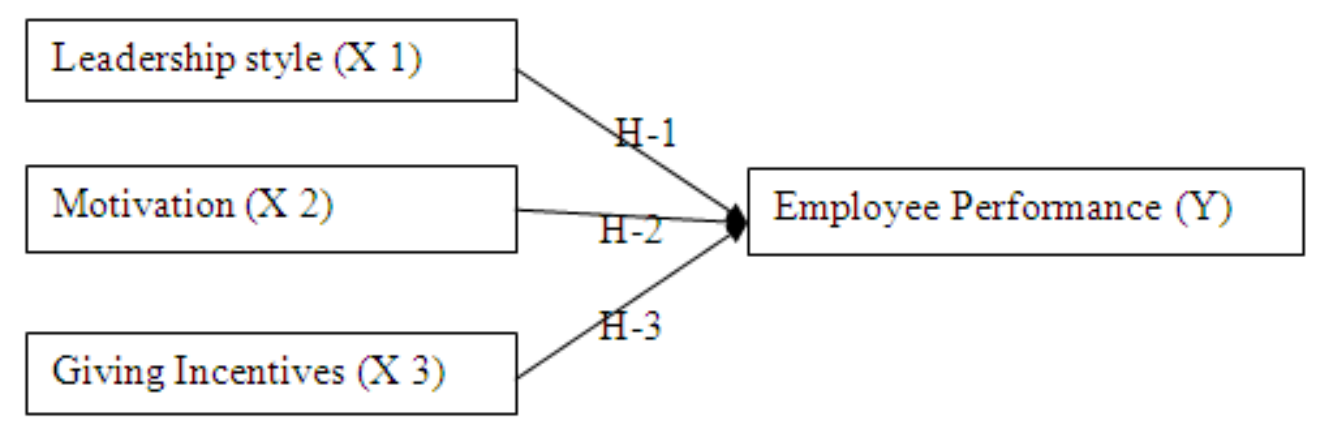

\section{Picture Frame concept}

\section{Methods}

\subsection{Population}

Population is the generalization region consisting of the objects/subjects that have certain qualities and characteristics defined by the researchers to learn and then draw conclusions (Sugiyono, 2013). The population in this study was employees in the Sales Department MT PT. Kurnia Wijaya Various Industries in Sidoarjo, Indonesia, amounting to 20 people.

\subsection{Samples}

The sample is part of the number and characteristics of the population. When large populations, and researchers may not learn all that there is in the population, for example, because of limited funds, manpower and time, then the researcher can use the sample drawn from the population. What is learned from the sample, the conclusion will be enforced to the population. For the samples taken from the population must be truly representative (representative) (Sugiyono, 2013), samples in this study were employees in the Sales Department MT, amounting to 20 people. The sampling technique was using the saturation sampling techniques

\subsection{Research Variables}

The independent variable $(\mathrm{X})$ and the dependent variable $(\mathrm{Y})$ in this study are:

a) Leadership Style (X1)

b) Motivation (X2) 
c) Incentives (X3)

d) Employee Performance (Y)

\subsection{Operational Definition of Variables (ODV)}

In this study the researchers define the operational variables as follows:

1) Leadership style

The independent variable (X1), namely: leadership style is the way leaders influence others or subordinates such a way that the person is willing to do the will of the leadership to achieve organizational goals.

2) Motivation

The independent variable (X2), namely: Motivation is a force resulting from a person's desire to satisfy his needs.

3) Incentives

The independent variable (X3), namely: Incentives are additional remuneration granted to certain employees who perform work in high performance.

The dependent variable (Y), namely: the attainment of performance is the result of efforts that have been done that can be measured by certain indicators.

\subsection{Research Instrument}

The research instrument used by other researchers using:

1) Documentation

According Arikunto (2010), documentation methods is to find data about things or variables in the form of notes, transcripts, books, newspapers, magazines, inscriptions, and minutes of meetings, Lengger, agendas and so forth.

2) Questionnaire

According to Sugiyono (2013, p. 23), questionnaire or questionnaire method is a technique of data collection is done by giving a set of questions or a written statement to the respondents (employees) to be answered, the form of a question consists of four indicators that is Leadership Style (X1), motivation (X2 ), Incentives (X3) and Employee Performance (Y).

\subsection{Data Analysis Techniques}

\subsubsection{Testing Instrument Research}

\subsubsection{Validity}

Validity test used to measure the validity of a questionnaire. A questionnaire as valid if the questions on the questionnaire were able to express something that is going to be measured. A question is valid if produced significant levels $<5 \%$, and vice versa if the generated significant levels $>5 \%$, the statement is invalid.

\subsubsection{Reliability Test}

Reliability refers to the notion that a measuring instrument sufficiently reliable to be used as a data collection tool, as a tool is already good measure. Calculation of reliability point in this study using the facilities provided by SPSS for measuring reliability with Cronbach Alpha statistical test $(\alpha)$, which is a construct or variable said to be reliable if the Cronbach's alpha value $\geq 0.60$. Classical Assumption Test

\subsubsection{Data Normality Test}

Normality test is used to determine whether the data is normally distributed or not. Such parametric linear regression analysis requires that the data must be distributed normally. Decision-making methods to test for normality that if significance (Asymp.Sig) $>0.05$, the normal distribution of data and if the significance (Asymp.Sig) $<0.05$ then the data is not normally distributed.

\subsubsection{Multicollinearity Test}

Multicollinearity test is a condition where between two or more independent variables in the regression model occurs linear relationship perfect or near perfect. Good regression model requires the absence of multicollinearity problem. To detect the presence or absence of multicollinearity there are several methods, among others, by comparing the value of R2 to R2 regression results or by looking at the value of tolerance and VIF. Methods of decision-making that is if the smaller the greater the value of tolerance and VIF, the closer the multicollinearity problem. In most studies say that if the tolerance is more than 0.1 and less than 10 , the VIF not 
happen multicollinearity.

\subsubsection{Heteroskidastity Test}

Heteroscedasticity test is a condition where the inequality of variance of the residuals in the regression model. Good regression model requires the absence of heteroscedasticity problem. To detect the presence or absence of heteroscedasticity there are several methods, among others, by means of Spearman's rho test is to correlate the residual value of the regression results with each of the independent variables and to see patterns in scatterplots full stop -point regression. Methods of decision-making on Spearman's rho test that if the value of the significance of the independent variables with residuals greater than 0.05 then there is no heteroscedasticity problem, but if the significance of less than 0.05 , then there is a problem of heteroscedasticity. While the method of decision-making by looking at the scatter plot that if the points spread with no clear pattern above and below the number 0 on the $\mathrm{Y}$ axis, it can be concluded that the regression model heteroscedasticity problem does not occur.

\subsubsection{Autocorrelation Test}

Autocorrelation test is a state in which the correlation of the residuals for the observation of one with the other observations in the order of time series. Good regression model requires the absence of autocorrelation problem. To detect the presence or absence of autocorrelation that is using the Durbin-Watson test (DW test) with the following conditions if:

1) DW value $<1.10$; no autocorrelation

2) DW value between 1.10 s.d 1.54; without conclusion

3) DW value between 1.55 s.d 2.46; no autocorrelation

4) DW value between 2.46 s.d 2.90; without conclusion

5) Value DW > 2.91; no autocorrelation

\subsection{Regression Analysis}

In this study, there are two independent variables namely job training (X1) and motivation (X2), and the dependent variable is the performance of the employee $(\mathrm{Y})$. The researchers used multiple linear regression analysis to determine the effect of independent variables on the dependent variable. The formula or equation used is as follows:

$$
\mathrm{Y}=\mathrm{a}+\mathrm{b}_{1} \mathrm{X}_{1}+\mathrm{b}_{2} \mathrm{X}_{2}
$$

Where is:

$\mathrm{Y}=$ Work Productivity

$\mathrm{a}=$ constant

b1, b2 = Coefficient Regression

$\mathrm{X} 1=$ Motivation

$\mathrm{X} 2$ = Work Discipline

\section{Data Analysis and Discussion}

\subsection{Data Analysis}

From the analysis using multiple linear regressions obtained the following results:

\subsubsection{Correlation Coefficient (R)}

Based on the Model Summary b 5:12 table that the multiple correlation coefficient of $R=0.985 \mathrm{a}$, it indicates that the degree of correlation between leadership styles, motivation and incentives to employees performance is very strong.

\subsubsection{The Coefficient of Determination (R 2/R Square)}

Based on the model Summary b 5:12 table that value determination coefficient R2 $=0.971$, this shows that the independent variable (style of leadership, motivation and incentives) together can affect the dependent variable (performance of employees) at $97.1 \%$ while the rest of $2.9 \%$ influenced by other factors not examined.

\subsubsection{The Regression Line Equation}

Based on coefficients a 5:18 table above can be made a regression equation to determine the effect Motivation 
and Discipline Work on Work Productivity as follows:

$$
\mathrm{Y}=-3169+02140587 \mathrm{X} 1+\mathrm{X} 2+\mathrm{X} 30750
$$

Based on the results obtained equations can be explained the meaning and significance of the regression coefficients are as follows:

a) Constant (a) $=-3.169$, this means that if the style of leadership, motivation and incentives for zero, then the performance of employees decreased by 3,169 units.

b) The coefficient $\mathrm{b} 1=0.214$, this means that if the leadership style (X1) is increased by 1 unit, then the employee's performance ( $\mathrm{Y}$ ) will increase by 0.214 units.

c) The coefficient $\mathrm{b} 2=0.587$, this means that if the motivation (X2) is increased by 1 unit, then the employee's performance $(\mathrm{Y})$ will increase by 0.587 units.

d) The coefficient $\mathrm{b} 3=0.750$, this means that if incentives (X3) is increased by 1 unit, then the employee's performance $(\mathrm{Y})$ will increase by 0.750 units.

\subsection{Discussion}

To perform testing of the hypothesis by using t-test can use the following steps:

a) If the sig. $<0.05$ then $\mathrm{HO}$ is rejected and Ha accepted. Which means that the hypothesis testing proved significantly.

b) If the sig. $>0.05$ then $\mathrm{H} 0$ is accepted and Ha rejected. Which means testing the hypothesis is not proven significantly.

Based on the results of $t$-test analysis on the obtained $t$ leadership style variable (X1) of 2.478 with sig. $0.025 ; \mathrm{t}$ arithmetic motivation variable (X2) is 5.869 with sig. 0,000 ; $t$ arithmetic variable incentives (X3) of 8.494 with sig. 0.000 . While $\mathrm{F}$ arithmetic independent variable on the dependent variable of 177.645 with sig. 0,000 . The results of hypothesis testing can be described as follows:

a) Leadership style (X1) sig. $0.025<0.05$, which means that the style of leadership affect the performance of the employees accepted/proven.

b) Motivation (X2) sig. $0.000<0.05$, which means that motivation affects the performance of the employees accepted/proven.

c) Incentives (X3) sig. $0.000<0.05$, which means that incentives affect the performance of the employees accepted/proven.

d) The style of leadership, motivation, and incentives sig. 0.0000 .05 , which means that the style of leadership, motivation, and $\leq$ incentives affect the performance of the employees accepted.

\section{Conclusions and Suggestions}

Based on the results of data analysis and hypothesis testing, it can be concluded as follows:

The value of multiple correlation coefficient of $\mathrm{R}=0,985 \mathrm{a}$, it indicates that the degree of correlation between leadership style (X1), motivation (X2), and the provision of incentives (X3) on employee performance (Y) is very strong. This is because the value of the correlation coefficient is $\mathrm{R}=0,985 \mathrm{a}$ is in the interval between 0.80 coefficient of 1.000 . While the coefficient of determination of $\mathrm{R} 2=0.971$, this shows that the independent variable (style of leadership, motivation, and incentives) together can affect the dependent variable (performance of employees) at $97.1 \%$ while the remaining $2.9 \%$ is affected by other factors not examined.

The initial hypothesis/H0 states that:

a. Allegedly there is the influence of leadership style on employee performance.

b. Allegedly there is the influence of motivation on employee performance.

c. Allegedly there is the influence of incentives on employee performance.

d. Allegedly there is the influence of leadership style, motivation, and incentives to employees' performance. Alternative hypothesis/Ha stated that:

a. T count leadership style variable (X1) based on the table coefficients of 2.478 with sig. 0.025 so $(0.025<0.05)$, which means that $\mathrm{HO}$ is rejected and $\mathrm{Ha}$ accepted, in other words proven leadership style has influence on employee performance significantly.

b. T count motivation variable (X2) based on the table coefficients of 5.869 with sig. 0.000 so $(0.000<0.05)$, 
which means that $\mathrm{H} 0$ is rejected and $\mathrm{Ha}$ accepted, in other words the motivation shown to have an influence on employee performance significantly.

c. T count variable incentives (X3) based on the table coefficients of 8.494 with sig. 0.000 so $(0.000<0.05)$, which means that $\mathrm{H} 0$ is rejected and $\mathrm{Ha}$ accepted, in other words, the provision of incentives is shown to have an influence on employee performance significantly.

d. F count independent variable (style of leadership, motivation, and incentives) to variable bound (employee performance) obtained a value of 177.645 with sig. 0,05$)$ which means that $\mathrm{H} 0$ is rejected and Ha accepted, $\leq$ 0,000 so $(0,000$ in other words the style of leadership, motivation, and incentives shown to have an influence on employee performance significantly.

Suggestions can be submitted on the results of this study are as follows:

a. Leaders should be able to provide concrete examples that can affect employees in more in order to improve employee performance.

b. Motivation of employees should be increased, giving rise to a new spirit in carrying out their duties that will have an impact on employee performance.

\section{References}

Arikunto, S. (2010). Research Procedure A Practical Approach. Jakarta. Rineka Reserved.

Brenninkmeyer, L. D., \& Spillane. (2008). Problem-solving processes of expert and typical school principals:a quantitative look. School Leadership and Management, 28(5), 435-468.

Burns, J. M. (1978). Leadership. New York: Harper and Row.

Chen, G., \& Tesluk, P. E. (2012). Team participation and empowerment: A multilevel perspective. In S. W. J. Kozlowski (Ed.), The Oxford handbook of organizational psychology (pp. 767-788). New York, NY: Oxford University Press. http://dx.doi.org/10.1093/oxfordhb/9780199928286.013.0024

Chen, G., Kirkman, B. L., Kanfer, R., Allen, D., \& Rosen, B. (2007). A multi-level study of leadership, empowerment, and performance in teams. Journal of Applied Psychology, 92, 331-346. http://dx.doi.org/10.1037/0021-9010.92.2.331

Chen, G., Sharma, P. N., Edinger, S. K., Shapiro, D. L., \& Farh, J. (2011). Motivating and demotivating forces in teams: Cross-level influences of empowering leadership and relationship conflict. Journal of Applied Psychology, 96, 541-557. http://dx.doi.org/10.1037/a0021886

Chen, P. Y., \& Spector, P. E. (1992). Relationships of work stressors with aggression, withdrawal, theft and substance use: An exploratory study. Journal of Occupational and Organizational Psychology, 65, 177-184. http://dx.doi.org/10.1111/j.2044-8325.1992.tb00495.x

Chen, Y. F., \& Tjosvold, D. (2006). Participative leadership by American and Chinese managers in China: The role of relationships. Journal of Management Studies, 43, 1727-1752. http://dx.doi.org/10.1111/j.1467-6486.2006.00657.x

Chen, Z., Lam, W., \& Zhong, J. A. (2007). Leader-member exchange and member performance: A new look at individual-level negative feedback-seeking behavior and team-level empowerment climate. Journal of Applied Psychology, 92, 202-212. http://dx.doi.org/10.1037/0021-9010.92.1.202

Department of Education. (2001). Dictionary of Indonesian. Jakarta: Central Library.

Duignan, P. A., \& Macpherson, R. J. S. (1992). Educative leadership: A practical theory for new administrators and managers. London: Falmer Press.

Effendi, O. U. (1992). Leadership and Communication. Jakarta: Mandar Maju.

Evans, M. G. (1970). The effects of supervisory behavior on the path-goal relationship. Organizational Behavior and Human Performance, 5, 277-298.

Evans, M. G. (1970). The effects of supervisory behavior upon worker perception of their path-goal relationships (Unpublished doctoral dissertation). Yale University.

Evans, M. G. (1996). R. J. House's ba path-goal theory of leader effectiveness Q. The Leadership Quarterly, 7, 305-309.

Gibson, J. L. et al. (1996). Organization, Behavior, Structure, Processes, trans. Nunuk Andiari. Jakarta: Binarupa Script. 
Handoko, H. T. (2001). Personnel management and resources. Man, Yogyakarta.

Hasibuan, M. S. P. (2002). Human resources management revised edition. Jakarta. Alphabet Earth.

Hasibuan, M. S. P. (2005). Organization and Motivation. Jakarta: PT. Earth Literacy.

Henry, S. (2004-610). Human resource management (3rd ed.). Publisher: STIE YKPN in Yogyakarta.

Hill, P. (2001). What principals need to know about teaching and learning. Victoria: Associationn of Registered Teachers of Victoria.

Hopkins, D. (2001). Schooling for Tomorrow: Innovation and Networks. OECD/CERI.

Hopkins, D. (2001a). School improvement for real. London: Falmer Press.

Hopkins, D. (2001b). Meeting the challenge: An improvement guide for schools facing challenging circumstances. London: DfES.

Hopkins, D. (2002). Speech to the NCSL Leading Transformation Network Conference, Queen Elizabeth Conference Centre, London, July.

Hopkins, D., \& Jackson, D. (2002). Building Capacity for Leading and Learning (in press).

Hopkins, D., Ainscow, M., \& West, M. (1994). School Improvement in an Era of Change. London: Cassell.

House, R. J. (1971). A path-goal theory of leader effectiveness. Administrative Science Quarterly, 16, 321-338.

House, R. J. (1996). Path-goal theory of leadership: Lessons, legacy, and a reformulated theory. The Leadership Quarterly, 7, 323-352.

House, R. J., \& Dessler, G. (1974). The path-goal theory of leadership: Some post-hoc and a priori tests. In J. Hunt, \& L. Larson (Eds.), Contingency approaches to leadership (pp. 29-55). Carbondale, IL: Southern Illinois University Press.

House, R. J., \& Mitchell, T. R. (1974). Path-goal theory of leadership. Journal of Contemporary Business, 3, 81-97.

House, R. J., \& Podsakoff, P. M. (1994). Leadership effectiveness: Past perspectives and future directions for research. In J. Greenberg (Ed.), Organizational behavior: The state of the science (pp. 45-82). Hillsdale, NJ7 Lawrence Erlbaum Associates.

House, R. J., Rousseau, D. M., \& Thomas-Hunt, M. (1995). The meso paradigm: A framework for the integration of micro and macro organizational behavior. In L. L. Cummings, \& B. M. Staw (Eds.), Research in organizational behavior (Vol. 17, pp. 71-114).

Hoy, W. K., \& Miskel, C. G. (2008). Educational administration: Theory, research, and practice (8th ed.) Boston: McGrawHill.

Ivancevich, J., Konopaske, M., \& Matteson. (2008). Organizational Behavior and Management. Jakarta: Erlangga.

Marta, O. E. (2011). Analysis of Influence of Leadership Style and Organizational Culture on Organizational Performance: Responsiveness as an intervening variable (Unpublished thesis). Semarang: Diponegoro University.

Parlinda, V. (2012). Influence of Leadership, Motivation, Training, and Work Environment on Employee Performance at the Regional Water Company of Surakarta (Thesis published, Surakarta Muhammadiyah University of Surakarta).

Pasaribu, H. (2008). Effect of Implementation Work Incentives Employee Motivation Revenue Service North Sumatra Province (Unpublished thesis). Terrain: the Graduate School of Economics and Management University of North Sumatra.

Priyono. (2006). Introduction to management. Graha Science Press.

Priyono. (2011). Human resources management 2. Surabaya. Dharma Science Press.

Rival, V. (2010). Human Resource Management, International Edition. New York: McGraw-Hill.

Robbins, S. P. (2007). Organizational Behavior. Jakarta: PT. Prenhallindo.

Robbins. P. S. (2002). The principles of the Organization perlaku (5th ed.). Publisher Erlangga, Jakarta.

Sedarmayanti. (2007). Good Governance and Good Corporate Governance (Part Three). New York: CV. 
Mandar Maju.

Sergiovanni, T. J. (1992). Moral leadership: Getting to the heart of school improvement. San Francisco: Jossey-Bass.

Sergiovanni, T. J. (1995). The headteachership: A reflective practice perspective. Boston: Allyn and Bacon.

Sergiovanni, T. J. (1998). Value-added leadership: How to get extraordinary performance in schools. San Diego, CA: Harcourt Brace Jovanovich, Publishers.

Siagian, S. (2002). Management of Human Resources. Jakarta. Alphabet Earth.

Simamora, H. (1997). Human Resource Management (Matter II). Yogyakarta: STIE YKPN.

Singarimbun, M., \& Sofian, E. (2006). The Survey Research Methods (Editor), LP3ES, Jakarta.

Stoll, L., \& Fink, D. (1996). Changing our schools. London: Open University Press.

Sugiyono. (2007). Quantitative and Qualitative Research Methods. New York: Alfabeta.

Sugiyono. (2011). For Statistical research. Bandung. Alfabeta.

Surbakti, M. P. (2013). Analysis of Effect of Transformational Leadership and Motivation on Employee Performance (Unpublished thesis). Semarang: Diponegoro University.

Tampoe, M. (1998). Liberating leadership. London: The Industrial Society.

Wati, E. (2010). Effect of Independence, Leadership Style, Organizational Commitment, and Understanding the Employee Performance Dood Governance Government Auditor (Thesis published, Navan: University General Sudirman).

Yukl, G. (2005). Leadership in Organizations. (5th ed.). Jakarta: Index.

\section{Copyrights}

Copyright for this article is retained by the author(s), with first publication rights granted to the journal.

This is an open-access article distributed under the terms and conditions of the Creative Commons Attribution license (http://creativecommons.org/licenses/by/3.0/). 